\title{
Foraminifera in Late Elsterian-Holsteinian deposits of the Tornskov area in South Jutland, Denmark
}

BY

KAREN LUISE KNUDSEN 


\section{Abstract}

Foraminiferal faunas from marine Late Elsterian and Holsteinian deposits in the Tornskov borehole have been investigated. The faunal succession is correlated with the pollen zones of the same boring, and the assemblages are compared with Late Elsterian and Holsteinian faunas described from adjacent areas.

Arctic foraminiferal faunas at the base of the marine sequence at Tornskov indicate that a marine transgression occurred prior to the establishment of full interglacial conditions, i.e. in the Late Elsterian. Marine sedimentation continued during much of the Holsteinian Interglacial. The assemblages here indicate boreal, mainly sublittoral conditions and relatively open access to the North Sea. Evidence for withdrawal of the Holsteinian sea from the area is not recorded in the faunas at Tornskov, the uppermost part of the marine sequence having probably been removed by subsequent glacial erosion.

The general trend for corresponding deposits over the whole area of SW Denmark and N. Germany is that the regression took place before any indication of climatic deterioration is seen in either the fauna or the flora. 


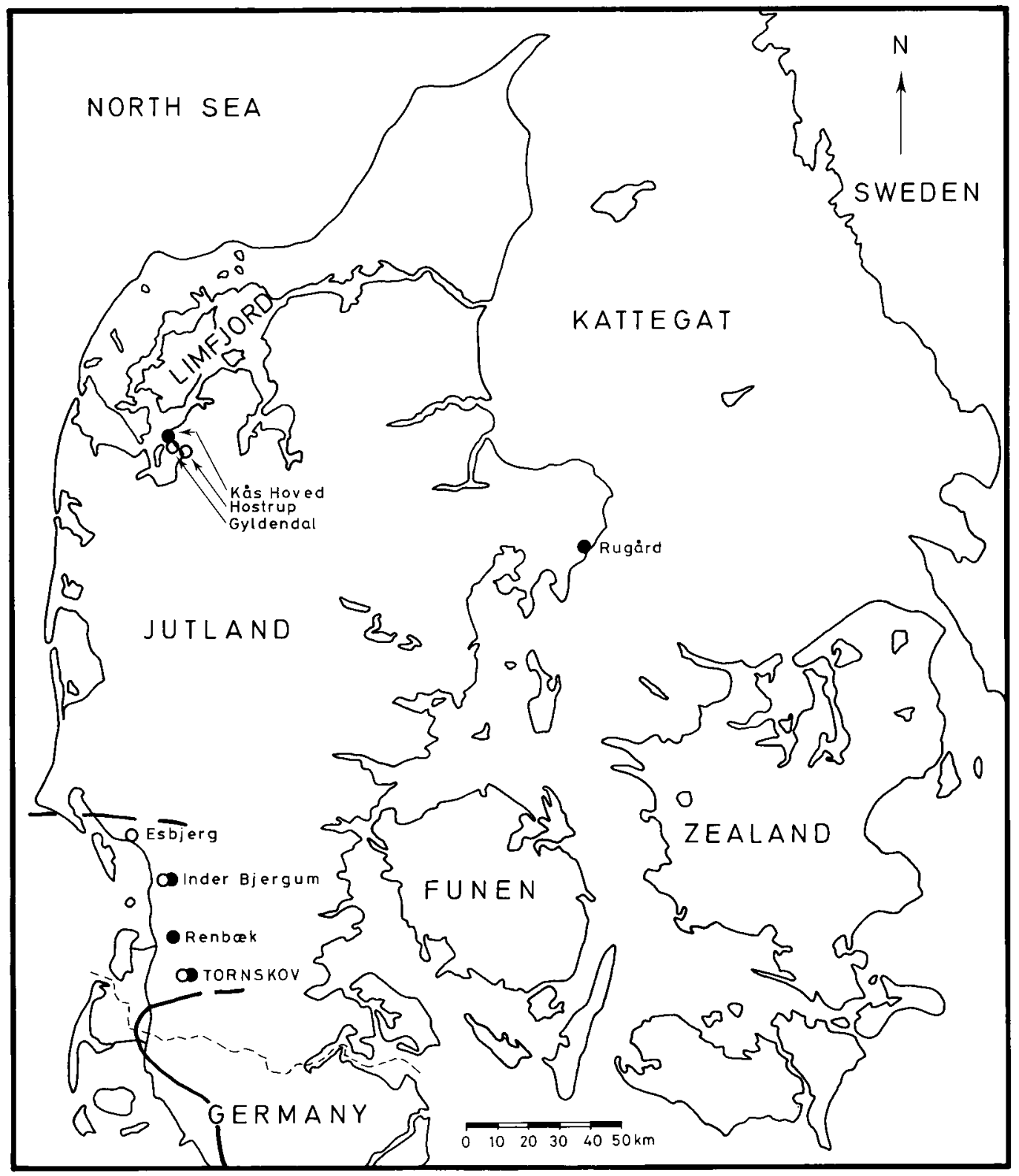

Fig. 1. Locality map. Open circles = marine Elsterian deposits; filled circles = marine Holsteinian deposits; solid line = Elsterian-Holsteinian coastline in SW Jutland. 


\section{Introduction}

A $107.6 \mathrm{~m}$ deep borehole at Tornskov in S. Jutland (figs. 1 and 2) penetrated marine and non-marine Quaternary deposits, and reached down into the marine Miocene. The boring was undertaken in 1958 by the Geological Survey of Denmark (Geol. Surv. file no. 159.243). The site is $22 \mathrm{~m}$ above sealevel, and was located at the edge of a hillisland of Saalian age (Milthers 1948), in an area which was not covered by ice during the Weichselian.

A rough description of the sediments in the boring was given by Leif Banke Rasmussen (in Andersen 1963), and a preliminary investigation of their foraminiferal content was undertaken by Buch (1963 and in Andersen 1963). A detailed pollen stratigraphy of the marine Quaternary deposits was, however, established by Andersen (1963), who referred pollen zones H1-H5 to the Holsteinian Interglacial.

The purpose of this investigation has been, firstly, to establish a detailed foraminiferal zonation of the Tornskov boring, secondly, to correlate these with Andersen's pollen zones, and thirdly, to interpret the environmental conditions at the site on the basis of the Foraminifera. The availability of

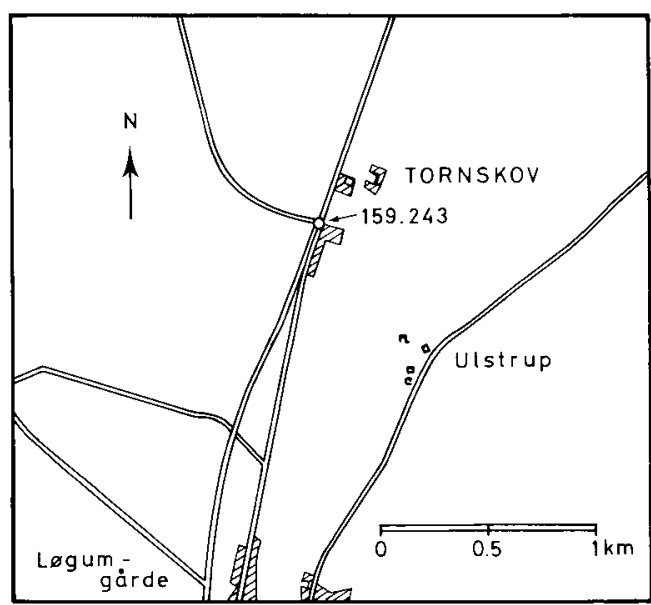

Fig. 2. The location of the Tornskov borehole. (From the Geodetic Institute map sheet 1112 II).

the same samples as were used in the pollen investigation enabled a comparison of the two methods, thus giving us an excellent opportunity to see how they could be coordinated. The knowledge obtained could, therefore, be used more productively in attempting a regional correlation, and in identifying the position of the Elsterian-Holsteinian boundary. 


\section{Methods}

A total of 115 samples from the Tornskov borehole were treated for foraminiferal analysis according to the laboratory methods described by Feyling-Hanssen et al. (1971) and Meldgaard \& Knudsen (1979). At least 300 specimens of Foraminifera were counted where possible. The frequency distribution of selected foraminiferal species is shown in the range chart (fig. 3 , p. 31). In samples with few Foraminifera the whole assemblage was counted. The actual number of tests for each species in the analysed samples has been entered in the range chart where this did not total 100 specimens.

The faunal diversity index used in the diagram was defined by Walton (1964) as the number of ranked species which accounts for $95 \%$ of a fauna, and the faunal dominance is the percentage of the most frequent species in each fauna (Walton 1964). Another diversity index was introduced by Pielou in 1979. This pielou index (p'3) was defined as the ratio between the third ranked species and the total amount of the three most frequent species in a fauna. This index, thus, supplements Walton's diversity index. The relationship between the three most important species in a sample might,

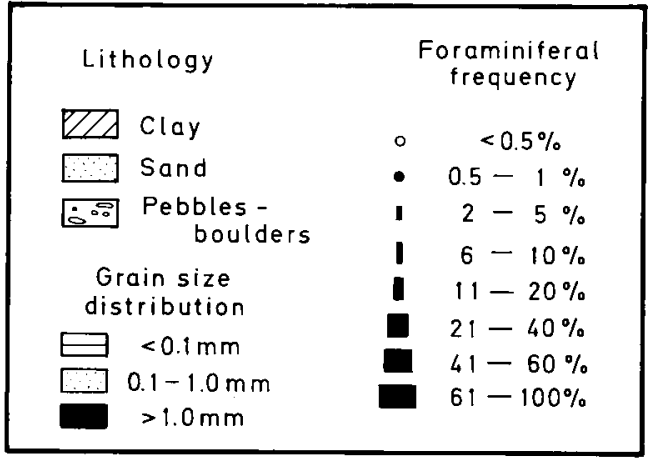

Fig. 4. Legend for fig. 3 (p. 31).

according to Pielou, be of value in palaeoenvironmental analysis.

A simplified outline of the lithology and grain size distribution is given on the left side of the range chart. Correlation with pollen zones (Andersen 1963) and a stratigraphical interpretation are shown to the right.

The foraminiferal "zones" in the present work are assemblage zones according to the definition given by Hedberg (1976). The term "zone" is used for the purpose of brevity only.

Fig. 3. Range chart for the Tornskov borehole (p. 31). The percentage distributions of the most common foraminiferal species are shown. Legend fig. 4. The bore site is $22 \mathrm{~m}$ above sea-level. 


\section{Foraminiferal zonation and palaeoecology}

The interval between 107 and $95 \mathrm{~m}$ in the Tornskov borehole is a massive sand, with laminae of sandy clay in the lower and upper part of the unit. This unit contains many Pre-Quaternary Foraminifera, mostly of Miocene origin, but with a few specimens from the Cretaceous. A few Quaternary Foraminifera occur in nearly all of the 15 analysed samples, and the unit is probably glacifluvial in origin, as Andersen concluded (1963) on the basis of the lithology and high frequency of Pre-Quaternary pollen.

This unit is overlain by a $56 \mathrm{~m}$ thick marine sequence, which can be subdivided into 5 foraminiferal assemblage zones (zone A to zone E, fig. 3). The upper $28 \mathrm{~m}$ of the borehole contain two non-marine units separated by about $8 \mathrm{~m}$ of marine sediments (fig. $3)$, which are presumably not in situ. Each of the marine zones and non-marine units is described in details below.

\section{Zone A. The Cassidulina reniforme - Elphidium excavatum zone}

The sediments between 95 and $92 \mathrm{~m}$ are composed of alternating layers of sand, silty clay, and clay. Foraminiferal faunas of samples 98-93 (fig. 3) are characteristically dominated by the the arctic forma clavata (see Feyling-Hanssen 1972) of Elphidium excavatum (66-82\%), and Cassidulina reniforme is also common (9-24\% of the total fauna.). The most important accessory species are Nonion orbiculare and Elphidium hallandense, but specimens of Elphidium albiumbilicatum and E. asklundi also occur. Both the faunal diversity (3-4) and the p'3 indices $(0.04-0.07)$ are low compared to the succeeding zone.

The ecological parameters indicate extreme marine environmental conditions, and the faunal composition shows that an arctic environment prevailed during deposition (Nagy 1965, Elverhøi et al. 1980).

\section{Zone B. The Nonion orbiculare - Elphidium hallandense zone}

Zone B occurs between 91 and $80 \mathrm{~m}$ (fig. 3). The sediment is silty sand throughout. $\mathrm{El}$ phidium excavatum, forma clavata and Nonion orbiculare are dominant, accounting for $41-50 \%$ and $14-37 \%$ of the faunas, respectively. Other important species are Elphidium hallandense (8-20\%) and E. asklundi $(2-4 \%)$. Only in the uppermost sample are the latter two species less frequent.

The zone B faunas are mainly arctic in character, but the presence of Elphidium albiumbilicatum throughout indicates an amelioration in marine climatic conditions when compared with the zone A faunas. The slowly increasing frequencies of boreal species such as Ammonia batavus, Elphidium magellanicum, and Nonion germanicum herald a gradual rise in temperature. The high content of $N$. orbiculare and $E$. hallandense, together with the presence of $E$. asklundi and E. albiumbilicatum, are indicators of shallower conditions than during the deposition of zone A. Decreasing precentages of Cassidulina reniforme could also indicate this, but discharge of meltwater into the area could also have had a detrimental effect on that species (Buzas 1965, Knudsen 1982).

Both faunal diversity (5-7) and the p' 3 in- 
dex (0.09-0.23) are higher than in zone $A$, and the faunal dominance is lower (41-50) (fig. 3). All these parameters point to less severe conditions here than during the depostition of zone $A$.

\section{Zone C. The Elphidium excavatum - Nonion orbiculare zone.}

There is a marked change both in sediment type and in faunal composition at the zone $\mathrm{B} / \mathrm{C}$ boundary. The silty sand of zone $\mathrm{B}$ is overlain by a silty clay in the lowermost part of zone $\mathrm{C}$, and clay in the upper part. A characteristic element of the faunas in zone C (79-75 m) is the high content of Ammonia batavus, especially in the lower samples (11-25\%). Nonion orbiculare continues up into the zone, but with lower frequencies $(5-12 \%)$ than in zone B. The boreal forma selseyensis (Feyling-Hanssen 1972) of E. excavatum $(59-86 \%)$ dominates the assemblages.

The Foraminifera of zone $\mathrm{C}$ indicate the establishment of full interglacial (boreal) conditions, as most of the arctic species have completely disappeared. A relatively low faunal diversity and p' 3 index, together with high faunal dominance, suggests the presence of extreme environmental conditions. The very high numbers of specimens in sample 80 at the bottom of the zone $(23,000$ per $100 \mathrm{~g}$ sediment $)$ may indicate that there was an initial period of slow accumulation.

The water depth is difficult to estimate because of the unusual composition of the faunas. Assemblages with Nonion orbiculare as an important element of otherwise boreal faunas have not ben recorded from any Recent faunas in NW Europe, but this distinct species-association is quite often encountered in Eemian and Holsteinian deposits in Denmark and N. Germany.

Ammonia batavus occurs mainly as the large lobulate form, often with an umbilical plug, both in zone $\mathrm{C}$ and in the succeeding zones $\mathrm{D}$ and $\mathrm{E}$. This form is typical for Recent North Sea faunas, and its occurrence here, thus, suggests rather open conditions, with direct access to the North Sea during deposition of the whole marine interglacial sequence.

The ostracod faunas in zone $\mathrm{C}$ suggest similar, but at the same time slightly cooler conditions than exist in the North Sea at present (Penney present volume).

\section{Zone D. The Elphidium excavatum - Elphidium magellanicum zone.}

Silty clays were found between 74 and $43 \mathrm{~m}$. The assemblages here are dominated by $\mathrm{El}$ phidium excavatum, forma selseyensis (usually $40-75 \%$ ) and E. magellanicum (usually $10-30 \%$ ). The sudden appearance and importance of the latter species is one of the characteristic features of the zone, although Ammonia batavus is also quite well represented (mostly 5-15\%) throughout the zone. Especially typical for all the faunas is, however, the presence of many accessory species such as Elphidium albiumbilicatum, E. williamsoni, E. gerthi, E. margaritaceum, Nonion germanicum, $N$. depressulum, $N$. orbiculare, Cibicides lobatulus, and Quinqueloculina stalkeri.

This faunal composition suggests the existance of a stable, fully marine, sublittoral environment (Culver \& Banner 1978). Generally the faunal diversity and p'3 indices are higher and the dominance lower than in zone $\mathrm{C}$. The greater number of specimens in the lower part of zone $\mathrm{D}$ might be an indication of a period with a slow accumulation rate.

The Ostracoda also support this interpretation, as they suggest marine-climatic conditions compatible with those present in the North Sea today (Penney this volume).

\section{Zone E. The Elphidium excavatum - Ammonia batavus zone.}

The sediments of zone E (42-29 m depth) are silty clays grading upwards into a silty fine sand at the top. A short period with a more extreme marine environment would 
appear to have occurred at the beginning of this zone. Both faunal diversity and the p'3 index decrease, and are particularly low in samples 39 and 40 . There may have been a temporary change in the coastline during this period, which may have taken the form of the construction of some kind of a barrier preventing open access to the sea. In this lower part of zone E Ammonia batavus is a frequent species (18-26\%), together with the dominant Elphidium excavatum, forma selseyensis $(60-76 \%)$, and most of the accessory species disappear. These reappear upwards through the zone as more open conditions, similar to those present in zone $D$, return to the area. The decrease in specimen numbers in this upper sandier part presumably indicates a higher accumulation rate here, but may also have been influenced by differential post-depositional compaction of the sediments.

A characteristic feature of zone $E$ is higher frequencies of Buccella frigida (mostly 1-9\%, maximum 19\%) than in zone $\mathrm{D}$, where it never exceeds $1 \%$ of the total fauna. In the upper part of zone E, species such as Elphidium albiumbilicatum, E. williamsoni, and E. margaritaceum are slightly commoner than in any of the zone $\mathrm{D}$ faunas, but the actual palaeoenvironment cannot have been much different in the two zones.

The top of the marine sequence, thus, contains relatively open and deep water faunas indicating sublittoral environments. No shallower water zone is found here. If there was one, it must have been eroded away later, probably during the following glaciation (see below).

Ostracod assemblages at the base of zone $E$ are indicative of a shallow sublittoral environment with normal marine salinity
(Penney this volume), and they contain an indication of slightly warmer conditions than in the other foraminiferal zones of the borehole. The corresponding foraminiferal faunas do not, however, show any indication of a warming trend.

\section{The dislocated units}

The upper $28 \mathrm{~m}$ of the Tornskov borehole comprises three different lithological units, viz. two non-marine deposits separated by a unit of marine sediments.

Between 28 and $22.4 \mathrm{~m}$ depth the sediment is coarse sand and gravels at the base and sandy clay with stones (till) in the upper part. Seven samples from this unit have been analysed. One is unfossiliferous, and the other six contain a few Quaternary specimens. These were presumably redeposited from the underlying zones, as the species are the same. A few of the samples have quite a high Pre-Quaternary foraminiferal content, mainly of Miocene origin, but species from the Cretaceous also occur.

The sediment between 22 and $13.7 \mathrm{~m}$ depth is silty clay. The ten analysed samples (nos. 22-13) from this stratum contain rich foraminiferal assemblages. The composition of the faunas is very close to those found in the lower middle part of zone D (between samples no. 67 and no. 58), even though they are not exactly the same. Specimen numbers are, for instance, generally larger in samples 22-13 than in this part of zone D.

The uppermost $12 \mathrm{~m}$ of the borehole consists of alternating layers of sand, sand with pebbles, and stones, and in the upper part of sandy clay and fine sand. All twelve samples analysed here are unfossiliferous. 


\section{Correlation and age}

This section compares the foraminiferal zonation at Tornskov with the pollen stratigraphy established by Andersen (1963) from the same borehole. The Foraminifera are also compared with data from Inder Bjergum and Esbjerg, and from several localities in N. Germany and Jutland. The stratigraphic position of these deposits is discussed.

\section{The Tornskov zones, Foraminifera and pollen}

Andersen $(1963,1965)$ recorded a vegetational succession at Tornskov that is both clearly interglacial in character and similar to the Holsteinian succession recorded in marine and non-marine deposits in the Netherlands, Germany, and Poland (i.a. Hallik 1960, Brouwer 1949). The interpretation that the Tornskov sequence is Holsteinian in age has been supported by more recent pollen investigations in NW Europe (i.a. Menke 1968, Müller 1974; see also Menke \& Behre 1973). Amino acid measurements correspondingly point to a Late Elsterian-Holsteinian age for Tornskov (Knudsen \& Sejrup in prep.).

In his preliminary study of the foraminiferal content in the Tornskov borehole, Buch (1963 and in Andersen 1963) divided the marine sequence into three foraminiferal zones. He identified a lower arctic unit (called the Elphidium clavatum-Cassidulina crassa zone, 94-82 m depth), an intermediate unit representing an interval of rising temperature (called the Elphidium clavatum-Elphidium (Nonion) orbicularis zone, 81-77 $\mathrm{m}$ ), and an upper zone with faunas reflecting conditions similar to those in the present North Sea (called the Elphidium clavatum-Streblus beccarii zone, 76-27 m). A similar zonation has been found in the present study, but some of the zones have been further subdivided (figs. 3 and 5).

The zone $\mathrm{A}$ and $\mathrm{B}$ assemblages in Tornskov indicate a gradual transition from a high arctic marine environment to a milder climate with shallower waters in zone $B$. These two units are here referred to the Late Elsterian. The non-marine sandy deposit below zone A may be a glacigenic formation from the Elsterian, but it could also be from an even older period. The boundary between the Elsterian and the Holsteinian occurs where foraminiferal faunas show a marked change to warmer conditions at $79.5 \mathrm{~m}$ depth.

According to Andersen (1963), there is a high frequency of re-deposited Pre-Quaternary pollen in the lower part of the marine sequence, but from $94 \mathrm{~m}$ these are mixed with pollen of Quaternary age, which also partly may be secondary. Primary pollen from the contemporaneous vegetation may, however, also occur here (Pinus?, Betula, Juniperus, and herbaceous plants). Above $76 \mathrm{~m}$ depth, the number of contaminants decreases, while primary pollen increases in importance. At 77 and $76 \mathrm{~m}$ the pollen spectra indicate an early interglacial Pinus-Betula forest of a pioneer type, with relicts from forestless vegetation (zone H1, Andersen 1963). Pollen zone H1, together with zone $\mathrm{H} 2$, where the amount of Pinus pollen increases, consequently correspond to the lowermost of the Holsteinian foraminiferal zones, zone $\mathrm{C}$.

Foraminiferal zones $\mathrm{D}$ and $\mathrm{E}$ correspond to pollen zones $\mathrm{H} 3$ to $\mathrm{H} 5$. These three pol- 
len zones were subdivided later by Andersen $(1964,1965)$ into five zones, zone 3 to zone 7 (zone H3 (1963) was subdivided into zones 3, 4 and 5 (1964)). A typical Holsteinian pollen succession is seen in these zones. Zone H3 (1963) is rich in Pinus and Alnus. There is an increase in Carpinus to about $6 \%$ in zone $\mathrm{H} 4$, and $A$ bies appears. In zone $\mathrm{H} 5$ the Abies content reaches a maximum of $5 \%$.

There is no indication of a subsequent climatic deterioration in the upper part of the boring. This is the case for both the pollen and the Foraminifera. The vegetational succession, however, shows that a considerable part of the interglacial succession is represented in the marine sequence (Andersen 1963).

As mentioned above, no marine regression is seen in the foraminiferal faunas in the upper part of the marine sequence. Glaciers from the following glaciation, the Saalian, may have eroded the top of the marine sediments away. There is no indication of glacial disturbance in terms of repetition of sequences within the marine deposits between 95 and $29 \mathrm{~m}$ depth. That the layers may be slightly tilted, for instance in the upper part, cannot, however, be refuted.

Shallower water facies preserved at the top of the Holsteinian sequence in N. Germany all contain true interglacial faunas (Knudsen in prep.). The regression in the southern North Sea area would, thus, appear to have taken place prior to any climatic cooling.

The marine sequence between 22 and $13.7 \mathrm{~m}$ depth in the Tornskov borehole is probably a glacially dislocated block originating from a Holsteinian zone $\mathrm{D}$ deposit nearby. Andersen (1963) reached a similar conclusion on the basis of the pollen (see also fig. 3). As the Weichselian ice did not cover the present area, this dislocation must have taken place during the Saalian glaciation. The non-marine units below and above the marine block are, thus, probably glacigenic deposits (glacifluvials and tills) from the Saalian (see also Andersen 1963).

\section{Correlation with Inder Bjergum}

Marine Quaternary deposits similar to those at Tornskov were described by Buch (1955) from the Inder Bjergum No. 2 borehole south of Esbjerg (fig. 1) (Geol. Surv. file no. 140.82.b). Material left over from this investigation has been processed and reanalysed, and a foraminiferal zonation has been established on the basis of this material, in combination with the results already published by Buch.

Despite evidence for the occurrence of different environmental conditions during certain periods of deposition at Tornskov and at Inder Bjergum, it has been possible to make a correlation between the zones in the two areas (fig. 5). This foraminiferal correlation is also supported by pollen investigations on the same samples at Inder Bjergum (Andersen 1963).

Zone A in Tornskov, the Cassidulina reniform - Elphidium excavatum zone, also occurs at Inder Bjergum (zone $A_{I}$ ). The faunal composition is similar at the onset of the marine transgression at both sites.

An assemblage corresponding to that found in zone B, the Nonion orbiculare Elphidium hallandense zone, is only recorded from a single sample at Inder Bjergum, sample 21 from the interval between 62.5 and $57.5 \mathrm{~m}$ depth (Buch 1955, p. 635). Percentage distributions of the most common species are shown in fig. 6. Sample 21 (AB) contains relatively large numbers of Nonion orbiculare, Elphidium hallandense, and $E$. asklundi, but the dominant species are E. excavatum and Cassidulina reniforme. Sample 21 (KLK), from the same interval, contains $10 \%$ Quinqueloculina stalkeri, while the frequencies of $C$. reniforme, $E$. asklundi, and $N$. orbiculare have decreased markedly, and E. hallandense is totally absent. This faunal composition is similar to those found in two samples from the overlying interval (between 54.5 and 48.5 $\mathrm{m})$, where $Q$. stalkeri is a characteristic element of the faunas $(20(\mathrm{KLK})$ and 20 (AB), fig. 6), C. reniforme has disappeared, 


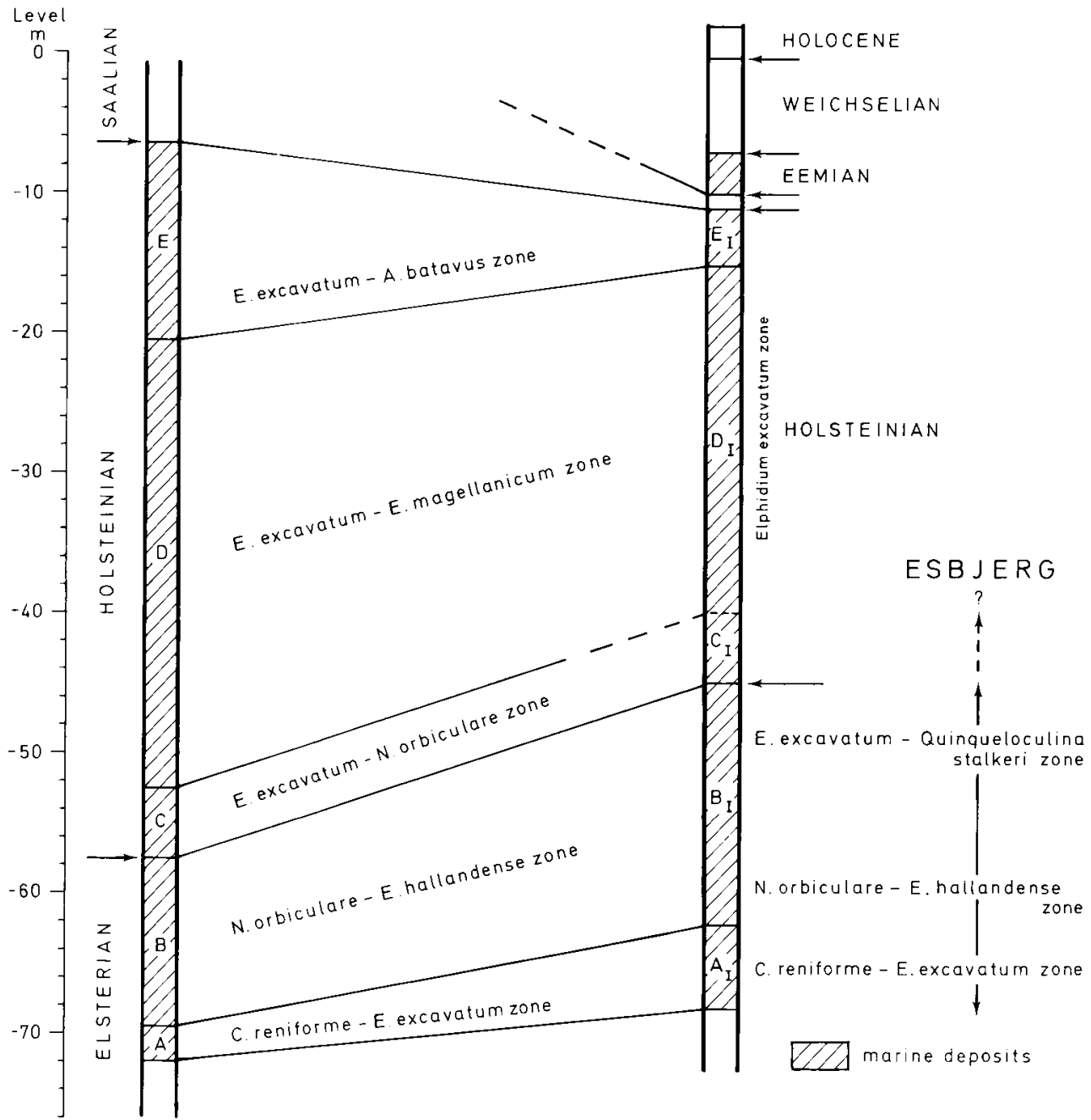

Fig. 5. Correlation of the foraminiferal zones in Tornskov and Inder Bjergum. Faunal types registered in samples from the clay pit of Esbjerg are shown to the right. The marine sediments at Esbjerg are, however, dislocated and found today at a much higher level, i.e. at about present-day sea-level.

and the dominance of $E$. excavatum is high (see also Buch 1955).

The above faunas show that different facies seem to be present within zone $\mathrm{B}_{\mathrm{I}}$ at Inder Bjergum. The species composition reflects an arctic environment, in the upper part maybe from deeper water than in the corresponding zone B at Tornskov. A decrease in the content of $C$. reniforme is, however, seen in the upper part of both zones.

The boundary between the Elsterian and the Holsteinian is placed at about $45 \mathrm{~m}$ below sea-level at Inder Bjergum. In the zone $C_{1}$ faunas above this boundary there is a marked change to boreal faunas. Elphidium excavatum is dominant, and the boreal species Ammonia batavus is always present. 
This boundary is, however, difficult to place accurately using Ostracoda (Penney this volume).

Zone $\mathrm{C}$ at Tornskov, with its characteristic content of Nonion orbiculare, can be compared with zone $\mathrm{C}_{\mathrm{I}}$ at Inder Bjergum. This correlation is also supported by pollen investigations. (Andersen 1963). Redeposited Tertiary pollen is abundant up to $45 \mathrm{~m}$ depth at Inder Bjergum. Betula, Pinus, and herbs also occur here in notable amounts. Above $45 \mathrm{~m}$ there is less redeposited material, and Alnus, Picea, and Quercus occur, together with other deciduous taxa. The change in pollen found in zone $C_{1}$ at Inder Bjergum correspond to similar changes in zone $\mathrm{H} 1$ and zone $\mathrm{H} 2$ within foraminiferal zone $\mathrm{C}$ at Tornskov.

The foraminiferal correlation higher up in the sequences is also supported by the pollen content. Abies pollen is, for instances, characteristic above $28 \mathrm{~m}$ depth in Inder Bjergum, which is within foraminiferal zone $D_{I}$. This is also the case in zone $\mathrm{H} 4$, which is in the upper middle part of foraminiferal zone $\mathrm{D}$ at Tornskov.

Zone D faunas, with Elphidium magellanicum as one of the dominant species, do not occur in Inder Bjergum. The corresponding sequence is totally dominated by $E$. excavatum and only a few accessory species occur. Ammonia batavus is, however, constantly present. Miliolids (Quiqueloculina stalkeri, $Q$. seminulum, and Miliolinella subrotunda) and some specimens of Bulimina marginata are present in the lowermost part of zone $D_{1}$ in Inder Bjergum. This indicates that salinity was probably higher at Inder Bjergum than at Tornskov during this period of deposition.

Zone $\mathrm{E}$ in the Tornskov boring is correlated with zone $\mathrm{E}_{\mathrm{I}}$ at Inder Bjergum (fig. 5) because of a similar increase in Ammonia batavus and the appearance of Buccella frigida here. In fact only the lower part of zone E contains faunas which are comparable with the assemblages found in zone $E_{I}$. A gradual increase in the frequency of the brackish, shallow water species Elphidium albiumbilicatum, together with the common occurrence of $A$. batavus, might be an indication of the beginning of a regression in the Inder Bjergum area. The top of the marine sequence may, however, also have been eroded away during the succeeding glaciation.

In a borehole at Renbæk, between Tornskov and Inder Bjergum (fig. 1), a similar Holsteinian foraminiferal succession is found between 13 and $33 \mathrm{~m}$ below present day sea-level (samples kindly placed at my disposal by Rud Friborg, Sønderjyllands Amtskommune, Tønder). Buccella frigida is also characteristic of the uppermost part of the marine sequence here (above $-23 \mathrm{~m}$ ). Marine Late Elsterian deposits do not, however, occur in this borehole. The marine Holsteinian rests directly upon a non-marine glacigenic deposit.

The foraminiferal faunas in the uppermost marine zone of the Inder Bjergum boring $(-7.2$ to $-10.2 \mathrm{~m}$, fig. 5) reflect marine environmental conditions which were warmer than those of the North Sea area today (see also Buch 1955). Lusitanean species, such as Elphidium translucens and $E$. lidoense, are characteristic faunal elements. These faunas correspond to those described from Eemian deposits in the Danish and $\mathbf{N}$. German areas (Lafrenz 1963, Konradi 1976, Knudsen 1985), and the sequence is, therefore, considered to be Eemian in age.

It must be mentioned here that the Inder Bjergum area is exceptional, because it is hitherto the only place in the whole Danish and N. German region where marine Eemian deposits have been described overlying the marine Holsteinian (Buch 1955, Mertz 1977). At Inder Bjergum these two marine interglacial units are only separated by relatively thin layers of non-marine deposits. In the Inder Bjergum 2 borehole, described here (fig. 5), this non-marine unit comprises only $1 \mathrm{~m}$ of silty clay, which may be a freshwater deposit. The marine Eemian deposits are separated from the Holsteinian by 0.3 to $3.2 \mathrm{~m}$ of glacifluvial sands and gravels in two adjacent boreholes (Buch 
1955). According to Mertz (1977) a Saalian till is present between the two interglacials in an area to the NE of Inder Bjergum.

\section{Correlation with Esbjerg}

The assemblages present in zone B at Tornskov and in zone $B_{I}$ at Inder Bjergum (20 and 21 , fig. 6) resemble those found in a clay pit in Esbjerg (fig. 1), the so-called "Esbjerg Yoldia Clay" (Jessen 1922, Hansen 1965). Assemblages from three different levels in this deposit are also shown in fig. 6. The level of the samples is not known, so they have been termed the lower, middle, and upper sample respectively.

The faunal succession in the three samples from Esbjerg corresponds closely to that described above from zone $B_{1}$, and, in addition, the lower sample from Esbjerg has a similar species composition as the bottom sample of zone B from Tornskov. Here Nonion orbiculare, Elphidium hallandense, and $E$. asklundi are important species, and the low percentage of Buccella frigida is also typical. A large number of Quinqueloculina stalkeri is typical for the upper Esbjerg sample, as it is at the top of zone $B_{I}$ in the Inder Bjergum boring. A suggested correlation of the sequences is given in fig. 5 .

Two additional samples (E1 and E2, fig. 6 , collected by Peter Willumsen) from the clay pit at Esbjerg may correspond to the upper part of the Esbjerg and Inder Bjergum sequences described above. The content of Cassidulina reniforme is extremely low, as is Ammonia batavus, but $Q$. stalkeri is lacking in both assemblages.

According to Buch (1955, p. 633) a zone A-type fauna has also been found in nine samples from the clay pit at Esbjerg (coll. Th. Sorgenfrei 1948). These results have been entered on the correlation chart (fig. 5).

The marine deposit at Esbjerg is generally assumed to be Late Elsterian-Holsteinian in age (Madsen 1895, Jessen 1922, Buch 1955, Feyling-Hanssen \& Knudsen 1979). The above faunal comparisons seem

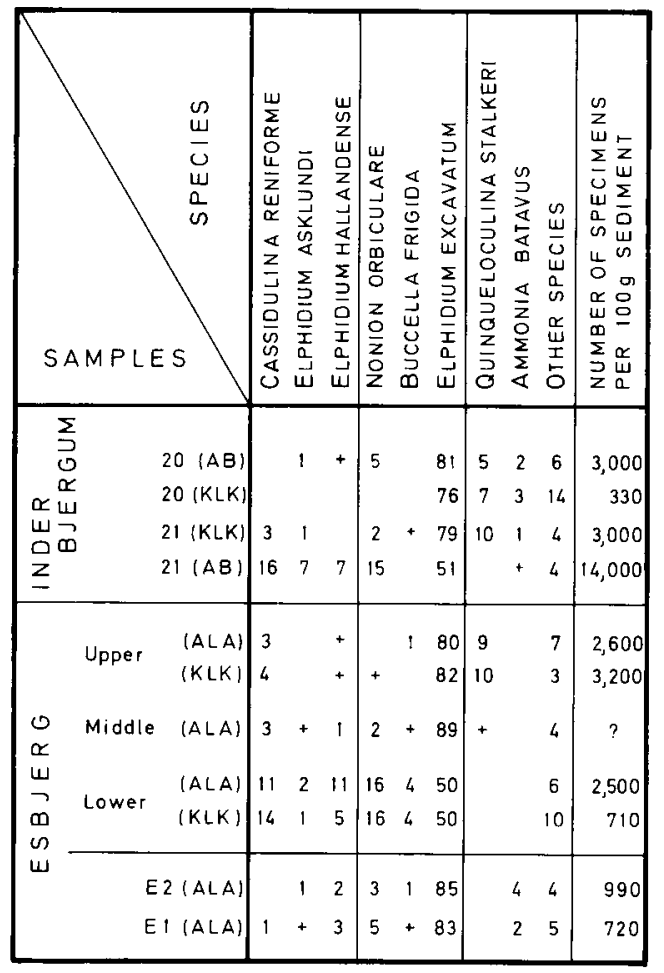

Fig. 6. Percentage distribution of the most common foraminiferal species in samples from zone $B_{I}$ of the Inder Bjergum borehole and from the clay pit at Esbjerg. Values less than $0.5 \%$ are marked with a cross. (AB)-Analyses from Buch (1955; Q. stalkeri was here referred to Sigmoilina distorta Phleger \& Parker 1951). (ALA)-Analyses placed at my disposal by Anne-Lise Lykke-Andersen. (KLK)-Additional analyses made by the author.

to support correlation with the Late Elsterian. Foraminiferal evidence for true interglacial conditions at Esbjerg has also recently been found (material kindly placed at my disposal by Mikael Jørgensen, Rambøll \& Hannemann A/S). The marine sediments are glacially disturbed at Esbjerg, and today they occur at about present-day sea-level. At Tornskov and Inder Bjergum, however, the Late Elsterian deposits are assumed to be undisturbed, and the sequences are found at much deeper levels (fig. 5).

Recent amino acid measurements made 
by Miller \& Mangerud (1986) suggest that the marine deposit at Esbjerg may be even older than the Elsterian. It is, therefore, clear that much more detailed biostratigraphical studies, combined with absolute dating, need to be carried out in the Esbjerg area to try to solve these stratigraphical problems.

\section{Late Elsterian - Holsteinian faunas in adjacent areas}

The foraminiferal faunas present in the Holsteinian deposits of the Tornskov borehole can be compared with those described from East Germany (Wiegank 1972) and N. Germany (Woszidlo 1962, Knudsen 1976 and 1980 ), but generally the species numbers are greater in the Tornskov faunas than in the corresponding deposits in Germany. This suggests a more open access from Tornskov to the North Sea.

The occurrence of the characteristic lobulate North Sea form of Ammonia batavus throughout the Holsteinian sequence at Tornskov also supports this interpretation. In most of the marine sequences known from N. Germany at least certain intervals are dominated by the brackish form of the same species (called $A$. batavus, var. $a$ by Woszidlo 1962 and Knudsen 1980). The lobulate form dominates all the Holsteinian assemblages only in the westernmost part of the Hamburg area and in borings at Cuxhaven (Knudsen in prep.).

The lusitanian species Aubignyna perlucida, which is common in many of the Holsteinian faunas in the $\mathrm{N}$. German region (Knudsen 1980), seems to decrease in importance northwards towards Denmark. $A$. perlucida occurs in most of the Holsteinian faunas at Tornskov and Inder Bjergum, but it usually does not exceed $1 \%$ of the total assemblages. The reason for this might be that A. perlucida is a typical shallow water species (Rosset-Moulinier 1972), and that conditions here were too deep. In shallow and brackish water Holsteinian sediments far- ther north in Denmark, however, $A$. perlucida also occurs only sporadically (Kronborg \& Knudsen 1985).

In an interglacial marine sequence of presumed Holsteinian age at Kirmington, E. England (kindly placed at my disposal by D. Gregory, British Geological Survey, Keyworth) the total faunas consisted of $A$. perlucida, and it is a common species also in the Holsteinian Nar Valley assemblages (kindly placed at my disposal by A. Lord, University College, London) from eastern England.

The restriction in distribution of the lusitanian faunal element to the southern and western parts of the North Sea region may mirror the geographical extent of lusitanian water masses in the area during the Holsteinian. It is not possible, however, on the basis of the present results, to tell whether these warmer water masses reached the North Sea through the English Channel or by currents north of Great Britain.

As is the case at Tornskov, a marine transgression also occurred in N. Germany in the Late Elsterian, but the deposits are dislocated at most of the sites, and an exact definition of the Elsterian-Holsteinian boundary is, therefore, not possible (Woszidlo 1962, Knudsen 1976 and 1980). This boundary has, nonetheless, recently been found in marine sediments in a deep boring at Eggstedt in Schleswig-Holstein, where it is believed to be undisturbed. The foraminiferal faunal succession here is closely comparable with the Tornskov assemblages (Knudsen in prep.). Zone A faunas are not recorded at Eggstedt, but the transition from a shallow boreal-arctic zone B-type fauna to boreal faunas close to the zone $\mathrm{C}$ assemblages is also found here. Moreover, the vegetational succession above the Elsterian-Holsteinian boundary at Eggstedt (B. Menke, pers. comm.) is also similar to that described from Tornskov.

Certain marine deposits in N. Denmark may also belong to the Elsterian and Holsteinian. These are, however, difficult to interpret, because practically all known find- 
ings here are glacially disturbed (Knudsen 1987).

Presumed Late Elsterian marine deposits have been recorded from several exposures and borings in the western Limfjord area (fig. 1), i.a. at Hostrup (Knudsen 1977) and at Gyldendal (Jensen \& Knudsen 1984). The faunal composition in these deposits are similar to the Elsterian Tornskov assemblages. A particular small and lobulate form of Cassidulina reniforme is also a characteristic element in the assemblages of both areas (see also Knudsen 1977).

Holsteinian Interglacial faunas have been described from Kås Hoved in the Limfjord (Jensen \& Knudsen 1984) and from Rugård in E. Jutland (Kronborg \& Knudsen 1985), and several other probable Elsterian and Holsteinian sites in the same areas are being worked on (Knudsen 1987).

As an aid in tying the chronology down more precisely, absolute dates are currently being made at many sites, i.e. amino acid measurements and thermoluminiscence datings. Preliminary results from Kås Hoved seem to support a Holsteinian age (Miller \& Mangerud 1986), while values from Gyldendal suggest an older age than the Elsterian (Knudsen \& Sejrup in prep.). TL-measurements from Rugård support the interpretation of a Holsteinian age (Kronborg pers. comm.). 


\section{Foraminiferal list}

The species mentioned in the text are arranged alphabetically in the following list. More than 50 other species were found in low numbers in the samples, but these have been excluded from the discussion, as they are not significant for the interpretation.

Ammonia batavus (Hofker 1951)

Aubignyna perlucida (Heron-Allen \& Earland 1913)

Buccella frigida (Cushman 1922)

Buccella frigida (Cushman), var. calida (Cushman \& Cole 1930)

Bulimina marginata d'Orbigny 1826

Cassidulina reniforme Nørvang 1945

Cibicides lobatulus (Walker \& Jacob 1798)

Elphidium albiumbilicatum (Weiss 1954)

Elphidium asklundi Brotzen 1943
Elphidium excavatum (Terquem), forma clavata Cushman 1930

Elphidium excavatum (Terquem), forma selseyensis (Heron-Allen \& Earland 1911)

Elphidium gerthi van Voorthuysen 1957

Elphidium hallandense Brotzen 1943

Elphidium lidoense Cushman 1936

Elphidium magellanicum Heron-Allen \& Earland 1932

Elphidium margaritaceum Cushman 1930

Elphidium translucens Natland 1938

Elphidium voorthuyseni Haake 1962

Elphidium williamsoni Haynes 1973

Fissurina Reuss 1850

Miliolinella subrotunda (Montagu 1803)

Nonion depressulum (Walker \& Jacob 1798)

Nonion germanicum (Ehrenberg 1940)

Nonion orbiculare (Brady 1881)

Quinqueloculina stalkeri Loeblich \& Tappan 1953 


\section{Summary}

The Tornskov borehole is situated at the edge of a Saalian hill-island in S. Jutland (fig. 1).

Foraminiferal faunas have been described from a continuous marine sequence reaching down into the Late Elsterian and comprising a major part of the Holsteinian Interglacial. The marine sequence, which rests upon a non-marine glacigenic deposit, is subdivided into five foraminiferal zones, zone A to zone E (fig. 3).

The lowermost zones, zone $A$ and zone $B$, from 95 to $80 \mathrm{~m}$ depth in the borehole, contain arctic Foraminifera at the bottom, but there is a gradual increase in the content of boreal species in zone B. These assemblages indicate that marine conditions first reached this area in Late Elsterian times.

Full interglacial conditions are established at the base of zone C. Only Nonion orbiculare remains as an important element of the faunas in this zone $(79-75 \mathrm{~m})$, together with the otherwise boreal species. The environment must have been similar to that in the North Sea today in zone $D$ and zone $E$ $(74-29 \mathrm{~m})$. The special lobulate form of Ammonia batavus and the large numbers of accessory species indicate quite open conditions with direct access to the North Sea during deposition of all the Holsteinian zones.

The faunal composition of zone $\mathrm{D}$ and the top of zone $E$ reflects rather stable environmental conditions as found in sublittoral areas, while the faunas of zone $\mathrm{C}$ and the lower part of zone $\mathrm{E}$ show that a more extreme environment prevailed during these periods of deposition.

Because the present foraminiferal investigation is made on the same sample material as used by Andersen (1963) for his pollen zonation, it has been possible to make a direct comparison of the results of both methods within the Holsteinian part of the sequence.

Zone H1 (fig. 3) contains pollen indicative of open-country vegetation and pioneer-type forest, while the zone $\mathrm{H} 2$ pollen reflects a closed canopy forest with increased amounts of Pinus at the expense of Betula (Andersen 1963). Andersen's results fit very well with my interpretation of a Late Elsterian-Holsteinian boundary between 80 and $79 \mathrm{~m}$ depth (at $57.5 \mathrm{~m}$ below present day sea-level, fig. 5).

Pollen zones $\mathrm{H} 3$ to $\mathrm{H} 5$, which equate with foraminiferal zones $\mathrm{D}$ and $\mathrm{E}$, clearly extend over a considerable part of the interglacial, and no indication of a climatic deterioration is seen in either flora or fauna in the upper part of the marine sequence.

The uppermost $28 \mathrm{~m}$ of the Tornskov borehole contains glacially disturbed layers comprising a lower unit of glacifluvials and tills from the Saalian, a block of marine Holsteinian deposits originating from a zone D-type sediment, and another glacigenic deposit of Saalian age at the top (fig. 3).

The foraminiferal zones at Tornskov are correlated with the faunal succession at Inder Bjergum and Esbjerg (fig. 5). Both the pollen and Foraminifera at Inder Bjergum indicate that the Elsterian-Holsteinian boundary occurs at about $45 \mathrm{~m}$ below sealevel. A similar succession is seen at Eggsted in N. Germany.

Scattered occurrences of both marine Elsterian and marine Holsteinian sediments are found at many localities in N. Germany and Denmark, but very often these are gla- 
cially dislocated, and the Elsterian-Holsteinian boundary is frequently lacking.

The Late Elsterian-Holsteinian coastline appears to have had deep and often wide embayments both in N. Germany and Denmark. The marine Tornskov and Inder Bjergum sequences are representative for the deposits in such embayments in SW Jutland.
There is a remarkable coincidence between the areal extent of the marine Elsterian and Holsteinian occurrences here and the PreQuaternary surface of the same area (see also Rasmussen 1966, p. 121). The transgression may, therefore, have been at least partially controlled by these structures. 


\section{Acknowledgements}

I am grateful to the Geological Survey of Denmark for placing material from the Tornskov and Inder Bjergum boreholes at my disposal. My sincere thanks to AnneLise Lykke-Andersen for permission to include her foraminiferal analyses from Esbjerg and for valuable discussions about the stratigraphy and to Dr. David N. Penney, Århus, for critically reading the manuscript and for improving the English text. I would also like to thank Svend Meldgaard, who processed the samples, Jette Gissel Nielsen for making the drawings and Lissi $\varnothing$. Mogensen for arranging the manuscript. 


\section{Dansk Sammendrag}

Foraminiferer i en sen Elster-Holstein lagserie ved Tornskov i Syd-Jylland, Danmark.

Tornskov boringen (fig. 1) er udført ved foden af glacialt højland fra Saale Istiden (kote $+22 \mathrm{~m}$ ).

Der er unders $\varnothing \mathrm{gt}$ foraminifer-faunaer fra en kontinuerlig marin lagserie, som omfatter aflejringer fra sen Elster og en større del af Holstein Interglacial tid. Denne marine lagserie, som overlejrer en ikke-marin glacial enhed, er inddelt $\mathrm{i}$ fem foraminifer-zoner, zone A til zone E (fig. 3).

I den nedre del af den marine serie (95-80 $m$ dybde) viser foraminifererne en udvikling fra højarktiske forhold i zone $A$ til gradvist mildere, men stadig hovedsagelig arktiske marin-klimatiske betingelser i zone $B$. Disse faunaer viser, at den marine transgression $\mathrm{i}$ dette område er startet allerede i sen Elster.

Ved overgangen til zone $C$ er der en markant ændring af faunaen, idet boreale arter nu bliver dominerende. Samtidig fortsætter arten Nonion orbiculare dog som et vigtigt element af faunaen gennem hele zone $\mathrm{C}$ (79-75 m). I zonerne D og E (74-29 m) svarer fauna-sammensætningen stort set til recente Nordsøfaunaer. Et indhold af relativt mange arter i de fleste prøver, samt den specielle lobulate form af Ammonia batavus viser, at der har været ret åbne forhold ud mod Nordsøen under aflejringen af hele det marine Holstein.

Zone $\mathrm{D}$ og den øvre del af zone $\mathrm{E}$ afspejler sublittorale forhold, mens der i zone $\mathrm{C}$ og den nedre del af zone $\mathrm{E}$ synes at have været mere ekstreme $\emptyset$ kologiske forhold.

Da foraminifer-undersøgelsen er lavet på det samme prøvemateriale, som Andersen anvendte til en pollen-stratigrafisk zonation af Holstein i 1963, har det her været muligt at foretage en meget nøjagtig sammenligning af resultaterne fra disse to forskellige stratigrafiske metoder.

Pollen-zonerne $\mathrm{H} 1$ og $\mathrm{H} 2$ repræsenterer birke-fyrreskov af pioner-type (Andersen 1963), som typisk udgør de første stadier af en interglacial skovudvikling. Dette passer godt med den faunistiske tolkning, som placerer grænsen mellem sen Elster og Holstein ved 79,5 $\mathrm{m}$ dybde (kote $-57,5 \mathrm{~m}$ ) (fig. 3 og 5). Pollen-zonerne $\mathrm{H} 1$ og $\mathrm{H} 2$ falder begge inden for foraminifer-zone $\mathrm{C}$.

Vegetationsudviklingen gennem pollenzonerne $\mathrm{H} 3-\mathrm{H} 5$ viser, at en stor del af interglacialtiden er repræsenteret $i$ den marine lagserie. Disse tre pollen-zoner svarer til foraminifer-zonerne D og E. Hverken i flora eller i fauna er der tegn på forværring af klimaet igen i den øvre del af lagserien. Dette er generelt for hele det nordtyske og det danske område, hvor regressionen af Holsteinhavet er foregået, mens der endnu herskede interglaciale forhold her.

De øverste $28 \mathrm{~m}$ i Tornskov boringen tolkes som glacialt forstyrrede lag. De omfatter en nedre ikke-marin enhed af glaciale sedimenter, en flage af det marine Holstein (fra zone D), og en $\emptyset$ vre glacial lagserie uden fossiler. Disse øvre enheder må være afsat under Saale glaciationen, idet Tornskov ligger udenfor Weichsel-isens maximale udbredelsesområde.

Foraminifer-zonerne i Tornskov er korreleret med en tilsvarende marin lagserie ved Inder Bjergum (Buch 1955), hvor grænsen mellem Elster og Holstein kan placeres ved kote ca. $-45 \mathrm{~m}$. Også her kan denne grænsedragning st $\varnothing t t e s$ af vegetationsudviklingen i området. Foraminifer-faunaer i prøver fra 
Esbjerg Teglværk tyder på, at de marine aflejringer her kan korreleres med zonerne A og B i Tornskov (fig. 5). Disse må således også formodes at være af sen Elster alder.

Mange steder i Nord-Tyskland og i Danmark findes spredte forekomster af marine aflejringer fra Holstein. Meget ofte er disse glacialt forstyrrede, og normalt er grænsen mellem Elster og Holstein ikke repræsenteret. I en boring ved Eggstedt i Nord-Tyskland forekommer dog uforstyrret en marin lagserie med en flora- og fauna-udvikling, der svarer nøje til den, som her er beskrevet fra Tornskov.
Kystlinien har under Elster-Holstein transgressionen været præget af dybe og ofte også brede fjorde, som har skåret sig ind i landet både i Nord-Tyskland og i Danmark. De marine lagserier ved Tornskov og Inder Bjergum repræsenterer aflejringer fra sådanne fjordsystemer. Udbredelsen af de marine Elster-Holstein aflejringer i SV Jylland svarer nøje til områder med en dybtliggende prækvartær overflade (se også Rasmussen 1966, p. 121), og transgression har sandsynligvis delvist været bestemt af disse strukturer. 
Andersen, S. T., 1963: Pollen Analysis of the Quaternary Marine Deposits at Tornskov in South Jutland. Danm. geol. Unders. IV Rakke 4 (8). 23 pp.

Andersen, S. T., 1964: Interglacial vegetational successions in the light of environmental changes. Report VI. International Congress on Quaternary, Warsaw 1961, 359-368.

Andersen, S. T., 1965: Interglacialer og interstadialer i Danmarks kvartær. Medd. dansk geol. Foren. 15 (4), 486-504.

Brouwer, A., 1949: Pollenanalytisch en geologisch onderzoek van het Onder- en Midden-pleistocaen van Noord-Nederland. Leidse Geol. Med. 14B, 259-346.

Buch, A., 1955: De marine interglaciale lag ved Inder Bjergum. Foraminiferfauna og stratigrafi. Medd. dansk geol. Foren. 12 (6), 593-652.

Buch, A., 1963: Marine kvartæraflejringers foraminiferfauna i Danmark. Medd. dansk geol. Foren. $15,240$.

Buzas, M. A., 1965: Foraminifera from Late Pleistocene Clay near Waterville, Maine. Smithsonian Misc. Coll. 145 (8). 30 pp.

Culver, S. J. \& Banner, F. T., 1978: Foraminiferal assemblages as Flandrian palaeoenvironmental indicators. Palacogeogr., Palaeoclimatol., Palaeoecol. 24, 53-72.

Elverhøi, A., Liestøl, O. \& Nagy, J., 1980: Glacial erosion, sedimentation and microfauna in the inner part of Kongsfjorden, Spitsbergen. Norsk Polarinst. Skr. 172, 33-60.

Feyling-Hanssen, R. W., 1972: The foraminifer $\mathrm{El}$ phidium excavatum (Terquem) and its variant forms. Micropaleontology 18 (3), 337-354.

Feyling-Hanssen, R. W., Jørgensen, J. A., Knudsen, K. L. \& Lykke-Andersen, A.-L., 1971: Late Quaternary Foraminifera from Vendsyssel, Denmark and Sandnes, Norway. Bull. geol. Soc. Denmark $21(2-3), 67-317$.

Feyling-Hanssen, R. W. \& Knudsen, K. L., 1979: Foraminiferer og deres betydning i skandinavisk kvartær geologi. Dansk Natur - Dansk Skole, Årsskrift 1979, 3-45.

Hallik, R., 1960: Die Vegetationsentwicklung der Holstein-Warmzeit in Nordwestdeutschland und die Alterstellung der Kiselgurlager der südlichen Lüneburger Heide. Z. deutsch. geol. Ges. 112, 326-333.
Hansen, S., 1965: The Quaternary of Denmark. 90 pp. In: Rankama, K. (editor): The Geologic Systems. The Quaternary 1. Interscience publishers, New York.

Hedberg, H. D. (ed.), 1976: International stratigraphic guide. A guide to stratigraphic classification, terminology and procedure. Wiley \& Sons, New York. 200 pp.

Jensen, J. B. \& Knudsen, K. L. 1984: Kvartærstratigrafiske undersøgelser ved Gyldendal og Kås Hoved i det vestlige Limfjordsområde. Dansk geol. Foren., Årsskrift for 1983, 35-54.

Jessen, A., 1922: Beskrivelse til det geologiske Kortblad Varde. Danm. geol. Unders. I Række 14. 105 pp.

Knudsen, K. L., 1976: Die Holstein-Interglaziale Foraminiferen-Fauna von Wacken (West-Holstein) und Hamburg-Hummelsbüttel. Eiszcitalter u. Gegenwart 27, 206-207.

Knudsen, K. L. 1977: Foraminiferal faunas of the Quaternary Hostrup Clay from Northern Jutland, Denmark. Boreas 6, 229-245.

Knudsen, K. L., 1980: Foraminiferal faunas in marine Holsteinian Interglacial deposits of Hamburg-Hummelsbüttel. Mitt. Geol.-Paläont. Inst. Univ. Hamburg 49, 193-214.

Knudsen, K. L., 1982: Foraminifers, 148-177. In: Olausson, E. (ed.): The Pleistocene/Holocene boundary in south-western Sweden. Sveriges geol. Unders. Ser C 794

Knudsen, K. L., 1985: Foraminiferal faunas in Eemian deposits of the Oldenbüttel area near the Kiel Canal, Germany. Geol. Jb. A86, 27-47.

Knudsen, K. L., 1987: Elsterian-Holsteinian foraminiferal stratigraphy in the North Jutland and Kattegat areas, Denmark. Boreas. (In press).

Konradi, P. B., 1976: Foraminifera in Eemian deposits at Stensigmose, southern Jutland. Danm. geol. Unders. II Række 105. 57 pp.

Kronborg, C. \& Knudsen, K. L., 1985: Om Kvartæret ved Rugård: en foreløbig unders øgelse. Dansk geol. Foren., Årsskrift for 1984, 37-48.

Lafrenz, H. R., 1963: Foraminiferen aus dem marinen Riss-Würm-Interglazial (Eem) in SchleswigHolstein. Meyniana 13, 10-46.

Madsen, V., 1895: Istidens Foraminiferer i Danmark og Holsten og deres Betydning for Studiet af Istidens Aflejringer. Medd. dansk geol. Foren. 2. 229 pp. 
Meldgaard, S. \& Knudsen, K. L., 1979: Metoder til indsamling og oparbejdning af prøver til foraminiferanalyser. Dansk Natur-Dansk Skole, Årsskrift 1979, 48-57.

Menke, B., 1968: Beiträge zur Biostratigraphie des Mittelpleistozäns in Norddeutschland. Meyniana $18,35-42$.

Menke, B. \& Behre, K. E., 1973: State of Research on the Quaternary of the Federal Republic of Germany. 2. History of Vegetation and Biostratigraphy. Eiszeitalter u. Gegenwart 23/24, 251267.

Mertz, E. L., 1977: Ribe og omegns jordbundsforhold. En ingeniør-geologisk beskrivelse. Danm. geol. Unders. Rapport 11. 52 pp.

Miller, G. H. \& Mangerud, J., 1986: Aminostratigraphy of European Marine Interglacial deposits. Quaternary Science Reviews 4 (4) (for 1985), 215278.

Milthers, V., 1948: Det danske Istidslandskabs Terrænformer og deres Opstaaen. Danm. geol. Unders. III Række 28. 233 pp.

Müller, H., 1974: Pollenanalytische Untersuchungen und Jahresschichtenzählungen an der Holstein-zeitlichen Kiselgur von Münster-Breloh. Geol. Jb. A21, 107-140.
Nagy, J., 1965: Foraminiiera in some bottom samples from shallow waters in Vestspitsbergen. Norsk Polarinst., Årbok 1963, 109 125.

Pielou, E. C., 1979: A quick method of determining the diversity of foraminiferal assemblages. J. Paleont. 53 (5), 1237-1242.

Rasmussen, L. B., 1966: Molluscan Faunas and Biostratigraphy of the Marine Younger Miocene Formations in Denmark. Part I: Geology and Biostratigraphy. Danm. geol. Unders. II Række 88 . 358 pp.

Rosset-Moulinier, M., 1972: Étude des Foraminifères des côtes nord et ouest de Bretagne. Trav. Lab. Géologie, E.N.S. 6. 225 pp.

Walton, W. R., 1964: Recent foraminiferal ecology and paleo-ecology, 151-237. In: Imbrie, J. \& Newell, N. D. (editors): Approaches to Paleoecology. Wiley \& Sons, New York.

Wiegank, F., 1972: Ökologische Analyse quartärer Foraminiferen. Beitrag zur Quartärstratigraphie in der nördlichen Deutschen Demokratischen Republik. Geologie 21, Beih. 77. $111 \mathrm{pp}$.

Woszidlo, H., 1962: Foraminiferen und Ostrakoden aus dem marinen Elster-Saale-Interglazial in Schleswig-Holstein. Meyniana 12, 65-96. 


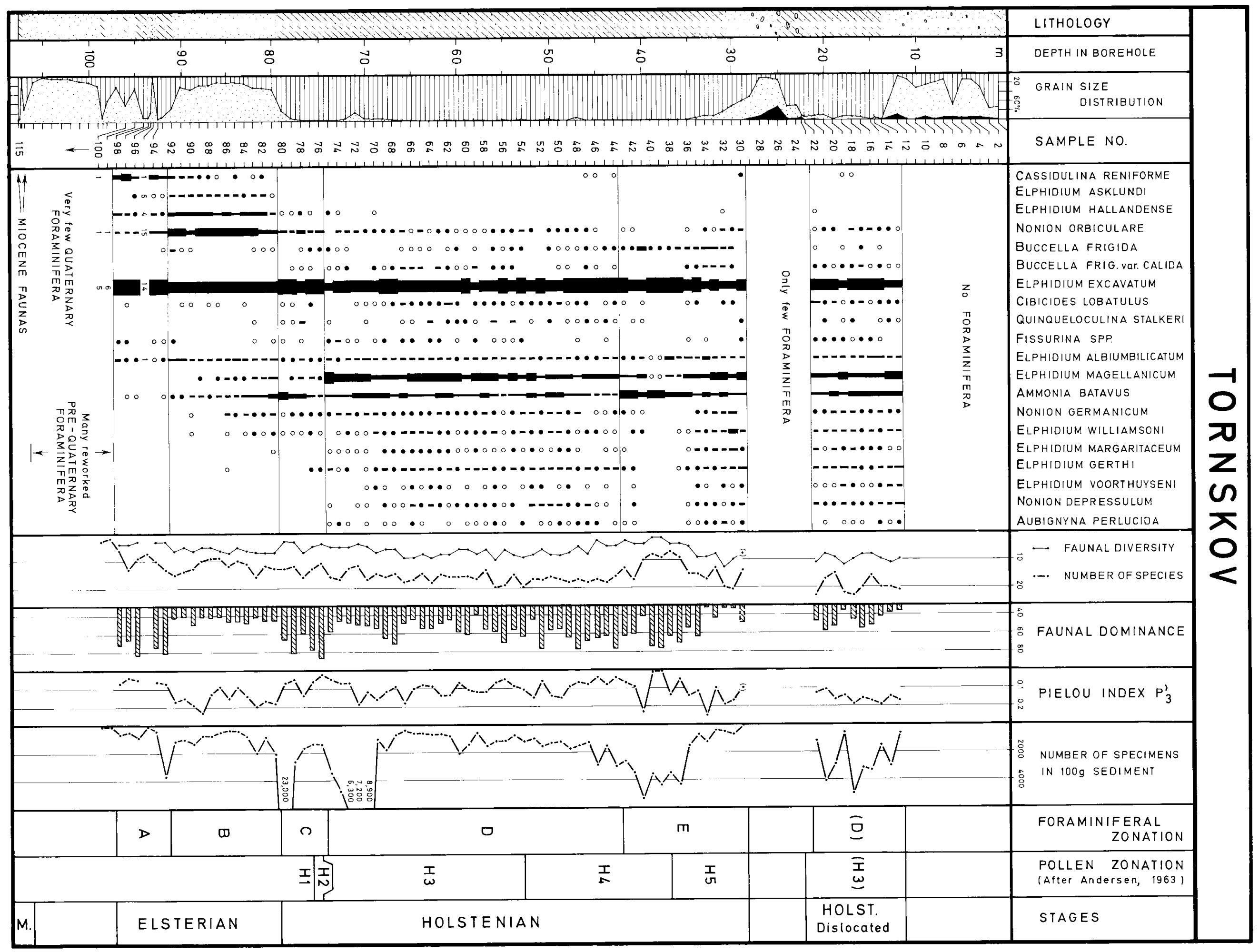

